\title{
Dietary patterns of primary school pupils according to their sex
}

\section{Zachowania żywieniowe dziewcząt i chłopców uczęszczających do wybranych szkót podstawowych}

\author{
Anna Dolipska, Aleksandra Góra', Karolina Janion², Elżbieta Szczepańska凶 \\ 1 Śląski Uniwersytet Medyczny w Katowicach, Studenckie Koło Naukowe Młodych Edukatorów, Zakład Żywienia Człowieka, ul. Jordana 19, 41-808 Zabrze \\ Medical University of Silesia in Katowice, Scientific Society of Young Educators, Department of Human Nutrition \\ ${ }^{2}$ Śląski Uniwersytet Medyczny w Katowicach, Zakład Profilaktyki Chorób Żywieniowozależnych, ul. Piekarska 15, 41-902 Bytom \\ Medical University of Silesia in Katowice, Department of Nutrition-Related Disease Prevention \\ ${ }^{3}$ Śląski Uniwersytet Medyczny w Katowicach, Zakład Żywienia Człowieka, ul. Jordana 19, 41-808 Zabrze \\ Medical University of Silesia in Katowice, Department of Human Nutrition \\ $\triangle$ eszczepanska@sum.edu.pl
}

\begin{abstract}
Introduction: Nutrition is one of the most important environmental factors affecting human health. The frequency, as well as the quality and quantity of consumed foods are significant. Regular and rational dietary habits and correct meal composition ensure good health and fitness, whereas poor dietary habits in childhood account for an early risk of overweightness and obesity. The aim of this study was to evaluate the dietary patterns of girls and boys attending primary schools in Poland, and to identify any associations between the pupils' dietary patterns and their sex. Materials and methods: The study was carried out in spring 2017. It covered a total of 1138 primary school pupils. A proprietary questionnaire specially designed for the study was used to investigate the pupils' dietary patterns. The findings were then analysed with the use of MS Excel 2010 and Statistica 12.0 software. Results: According to the survey, $67.36 \%$ of the female respondents and $55.4 \%$ of the male respondents ate the recommended number of meals each day. Among the respondents $72 \%$ of the girls and $73.27 \%$ of the boys reported eating breakfast daily.
\end{abstract}

Fruits and vegetables were eaten several times per day by $60.38 \%$ and $43.11 \%$ of girls, respectively, v. $50.44 \%$ and $32.39 \%$ of boys, respectively. The frequency of milk and natural yoghurt consumption was adequate in $20.07 \%$ and $10.12 \%$ of girls, respectively, v. $20 \%$ and $11.5 \%$ of boys. Sweets and salty snacks were excluded from the diet of $2.97 \%$ and $2.27 \%$ of girls, respectively, v. $3.19 \%$ and $2.12 \%$ of boys, respectively. Sweetened carbonated drinks were consumed by $11.17 \%$ of girls and $6.55 \%$ of boys. Fast food and instant foods were eliminated from the daily diet of $7.16 \%$ and $45.03 \%$ of girls, respectively, v. $6.02 \%$ and $43.19 \%$ of boys, respectively.

Conclusions: Some incorrect dietary habits were identified both in girls and boys, however girls generally reported more beneficial habits. Statistically significant associations were found between the majority of dietary patterns in the studied population and the respondents' sex. The results of the study indicate a need for more intense nutritional education among primary school pupils, diversified for boys and girls.

Keywords: dietary patterns; pupils; primary schools.

\section{ABSTRAKT}

Wstęp: Żywienie należy do najważniejszych elementów mających wpływ na zdrowie człowieka. Znaczenie ma zarówno częstość spożywania poszczególnych produktów spożywczych, jak i ich skład jakościowy oraz ilościowy. Nawyki regularnego i racjonalnego żywienia oraz prawidłowo zestawione posiłki zapewniają dobrą kondycję oraz zdrowie, zaś niewłaściwe żywienie w czasie dzieciństwa jest wczesnym czynnikiem ryzyka nadwagi i otyłości.

Celem pracy była ocena zachowań żywieniowych dziewcząt i chłopców uczęszczających do szkół podstawowych oraz stwierdzenie, czy istnieją zależności pomiędzy zachowaniami żywieniowymi uczniów i ich płcią.

Materiały i metody: Badanie przeprowadzono wiosną 2017 r. Wzięło w nim udział 1138 uczniów uczęszczających do szkół podstawowych. Do oceny posłużył autorski kwestionariusz ankiety. Wyniki analizowano przy pomocy programów MS Excel 2010 i Statistica 12,0.

Wyniki: Spożywanie zalecanej ilości posiłków zadeklarowało $67,36 \%$ dziewcząt i 55,4\% chłopców. Codzienne spożywanie śniadania zaznaczyło $72,2 \%$ dziewcząt oraz 73,27\% chłopców.
Kilkukrotne spożycie owoców i warzyw w ciągu dnia wykazało odpowiednio $60,38 \%$ i 43,11\% dziewcząt oraz 50,44\% i 32,39\% chłopców. Zalecaną częstość spożycia mleka i jogurtów naturalnych zadeklarowało odpowiednio $20,07 \%$ i 10,12\% dziewcząt oraz $20 \%$ i 11,5\% chłopców. Eliminację z diety słonych przekąsek i słodyczy deklarowało odpowiednio 2,97\% i 2,27\% dziewcząt oraz 3,19\% i 2,12\% chłopców. Wykluczenie słodzonych napojów gazowanych zaznaczyło 11,17\% dziewcząt i 6,55\% chłopców. Wykluczenie z diety produktów typu fast food oraz instant zadeklarowało odpowiednio 7,16\% i 45,03\% dziewcząt oraz 6,02\% i 43,19\% chłopców.

Wnioski: W zachowaniach żywieniowych dziewcząt i chłopców stwierdzono występowanie nielicznych nieprawidłowości, przy czym korzystniejsze zachowania zaobserwowano u dziewcząt. Stwierdzono występowanie istotnych statystycznie zależności pomiędzy większością zachowań żywieniowych uczniów i ich płcią. Wyniki badań wskazują na potrzebę prowadzenia edukacji żywieniowej wśród uczniów uczęszczających do szkół podstawowych, zróżnicowanej dla chłopców i dziewcząt.

Słowa kluczowe: zachowania ży wieniowe; uczniowie; szkoły podstawowe. 


\section{INTRODUCTION}

Adequate nutrition, optimal in regards to the quantity and quality of the consumed food, is a prerequisite for proper functioning of the human body. In the case of adolescents and young children, adequate nutrition plays an especially important role as it affects their proper development and should address the changing needs of the young body [1]. Proper nutrition implies consumption of foods which satisfy the body's energy needs adequately for a given person's age, sex and level of physical activity. Diet should be varied and contain sufficient amounts of protein, fat, carbohydrates, vitamins, minerals and water. The distribution of meals throughout the day alos plays a significant role [2]. According to the norms established by the Polish National Food and Nutrition Institute (Instutut Żywności i Żywienia), at a moderate physical activity level, children aged 7-9 years old exhibit daily energy expenditure of $1800 \mathrm{kcal}$, whereas among children aged 10-12 years old expenditure is $2350 \mathrm{kcal}$ for boys, v. 2100 kcal for girls [3].

Deficient nutrition, either in regard to the quantity or quality of the consumed food, has a detrimental effect on health, including impaired immune function and bone development and decreased cardiovascular and respiratory function. Irregular meals as well as poorly balanced diet increase the risk of diet-related diseases, such as atherosclerosis, obesity, osteoporosis and cancer $[4,5]$.

Family is the primary factor that influences children's dietary patterns, with school being nearly as important in shaping pupils' awareness surrounding health-promoting behaviours. Proper education is crucial, yet it must involve both children and their parents, as children are known to acquire and imitate the dietary patterns and entire nutrition models of their parents $[6,7,8]$. Unless promptly addressed, the multitude of dietary mistakes made by children may lead to a decreased quality and comfort of life in older age, in extreme cases even shortening lifespan $[2,5,9]$.

\section{MATERIALS AND METHODS}

The study was performed in spring 2017, and covered a total of 1138 students attending primary schools, including 573 (50.4\%) girls and $565(48.6 \%)$ boys. The detailed characteristic of the studied group are shown in Tables 1 and 2.

A dedicated survey questionnaire was used in the study, which consisted of a demographic section and the survey proper, containing questions regarding dietary patterns and the intake frequency of certain foods, consumed within the 30 days preceding the survey. The obtained results were then analysed with Microsoft Excel 2010 and statistical analysis was performed using Statistica 12.0 (Statsoft, Inc.) software. For the purpose of the statistical analysis, various response options in the questions concerning the frequency of food product consumption were pooled together, with the following options distinguished: every day, several times a week, several times a month, occasionally and/or never. The $\chi^{2}$ test was
TABLE 1. Characteristic of the studied group

\begin{tabular}{llll}
\multicolumn{1}{c}{ Feature } & & $\mathbf{n}$ & \% \\
\hline \multirow{2}{*}{ Sex } & girls & 573 & 50.4 \\
\cline { 2 - 4 } & boys & 565 & 48.6 \\
\hline \multirow{3}{*}{ Class } & IV & 339 & 29.8 \\
\cline { 2 - 4 } & $\mathrm{V}$ & 420 & 36.9 \\
\cline { 2 - 4 } & VI & 379 & 33.3 \\
\hline \multirow{2}{*}{ Voivodeship } & Śląskie & 483 & 42.4 \\
\cline { 2 - 4 } & małopolskie & 333 & 29.3 \\
\cline { 2 - 4 } & opolskie & 322 & 28.3 \\
\hline Total & & 1138 & 100.0 \\
\hline
\end{tabular}

TABLE 2. Age of the studied group

\begin{tabular}{lcccccc} 
& $\mathbf{n}$ & Median & Mimimum & Maximum & $\begin{array}{c}\text { Lower } \\
\text { quartile }\end{array}$ & $\begin{array}{c}\text { Upper } \\
\text { quartile }\end{array}$ \\
\hline Girls & 573 & 12 & 10 & 14 & 11 & 13 \\
\hline Boys & 565 & 12 & 9 & 14 & 11 & 13 \\
\hline Total & 1138 & 12 & 9 & 14 & 11 & 13 \\
\hline
\end{tabular}

used to analyse the significance of the relationship between the respondents' sex and their dietary patterns and the frequency of consumption of given foods. For all analyses, the level of statistical significance was set at $\mathrm{p}<0.05$.

\section{RESULTS}

Select dietary patterns among primary school pupils have been shown in Figures 1, 2, and 3.

The recommended 4-5 daily meals were eaten by $67.36 \%$ of girls v. 55.4\% of boys. Breakfast was eaten at home daily by $72.2 \%$ of girls v. $73.3 \%$ of boys. An adequate amount of water was drunk daily by $28.1 \%$ of girls v. $33.1 \%$ of boys.

A significant correlation between the respondents' sex and the number of meals eaten daily was identified $(\mathrm{p}<0.01$; $\mathrm{V}=0.13$ ), whilst no significant correlation was determined between the respondents' sex and the frequency of eating breakfast $(\mathrm{p}=0.97)$ or the amount of water drunk daily $(\mathrm{p}=0.97)$ - Figures 1, 2, and 3. The intake frequency of select foods is shown in Tables 3, 4, 5, and 6.

Analysis of the frequency with which plant-based products are eaten demonstrated that $17.2 \%$ of girls v. $17.7 \%$ of boys eat

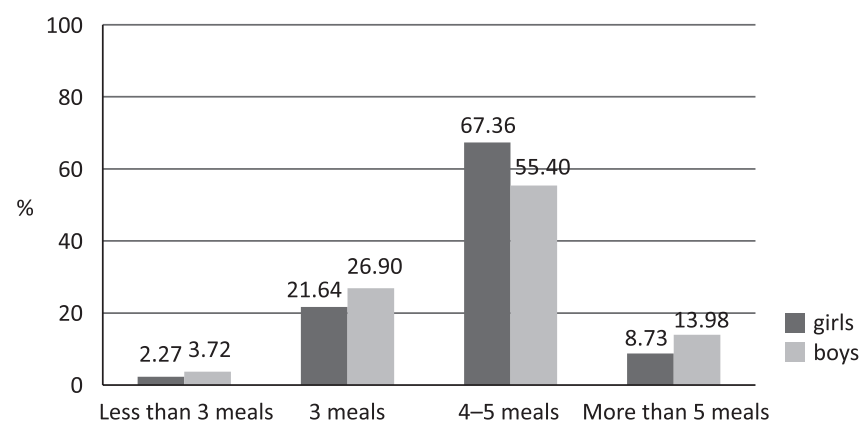

$\mathrm{p}$ value based on $X^{2}$ test; $V$ - value $V$-Cramer

FIGURE 1. The number of meals eaten daily, according to the respondents' $\operatorname{sex}(p<0.02 ; V=0.13)$ 


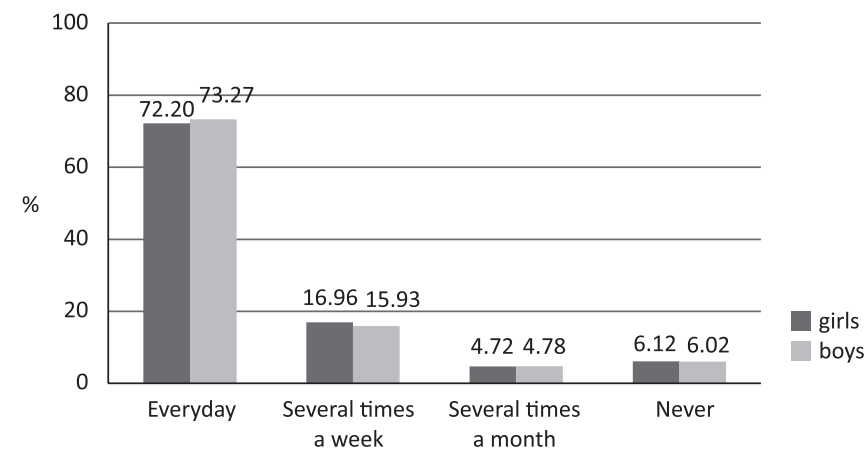

$\mathrm{p}$ value based on $x^{2}$ test

FIGURE 2. Breakfast eaten at home, according to the respondents' $\operatorname{sex}(p=0.97)$

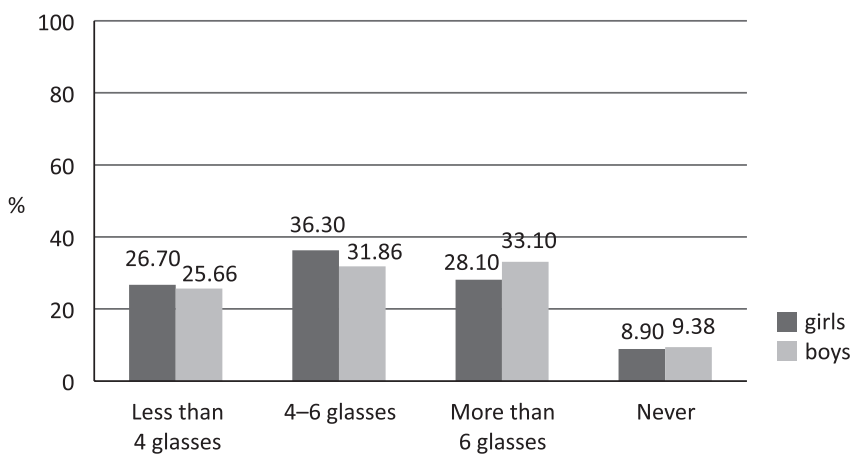

$p$ value based on $X^{2}$ test; $V$ - value $V$-Cramer

FIGURE 3. The number of glasses of water drunk daily, according the respondents' sex $(p=0.24)$

wholemeal bread several times per day. Fruit and vegetables are eaten several times per day by $60.38 \%$ and $43.11 \%$ of girls, respectively, v. $50.44 \%$ and $32.39 \%$ of boys, respectively (Tab. 3).

A significant correlation between the respondents' sex and the frequency of fruit $(\mathrm{p}<0.01 ; \mathrm{V}=0.11)$ and vegetable $(\mathrm{p}<0.01$; $V=0.14$ ) intake was found. The findings suggest that fruits and vegetables are eaten much more frequently by girls than boys.

Analysis of the intake frequency of animal-based products showed that milk and natural yoghurts were consumed daily by $20.07 \%$ and $10.12 \%$ of girls, respectively, v. $20 \%$ and $11.5 \%$ of boys, respectively. Cottage cheese was eaten by $13.26 \%$ of girls v. $17.35 \%$ of boys. Rennet-based and processed cheeses were eaten by $37.5 \%$ girls v. $31.68 \%$ of boys. Fish and meat ware consumed several times a week by $29.84 \%$ and $35.43 \%$ of girls respectively, v. $29.38 \%$ and $28.14 \%$ boys, respectively.

A significant correlation was identified between the respondents' sex and the frequency of natural yoghurt intake $(p=0.01$; $\mathrm{V}=0.12)$ and cottage cheese intake $(\mathrm{p}=0.01 ; \mathrm{V}=0.10)$. The obtained results suggest that the consumption frequency is lower in girls than in boys (Tab. 4).

Analysis of the intake frequency of snacks and sweetened carbonated drinks among primary school students indicated that $2.97 \%$ and $2.27 \%$ of girls, respectively, v. $3.19 \%$ and $2.12 \%$ of boys, respectively, eliminated salty snacks and sweets from their diet.

A significant correlation was demonstrated between the respondents' sex and the frequency of salty snack consumption ( $p<0.01 ; V=0.12$ ) and sweetened carbonated drink consumption
TABLE 3. Frequency of intake of plant-based foods, according to the respondents' sex

\begin{tabular}{|c|c|c|c|c|c|}
\hline \multirow{3}{*}{$\begin{array}{l}\text { Group } \\
\text { of food } \\
\text { products }\end{array}$} & \multirow{3}{*}{$\begin{array}{c}\text { Frequency } \\
\text { of intake of } \\
\text { selected foods }\end{array}$} & \multicolumn{4}{|c|}{ Sex } \\
\hline & & \multicolumn{2}{|c|}{ girls } & \multicolumn{2}{|c|}{ boys } \\
\hline & & $\mathrm{n}$ & $\%$ & $\mathrm{n}$ & $\%$ \\
\hline \multirow[t]{6}{*}{$\begin{array}{l}\text { Wholemeal } \\
\text { bread }\end{array}$} & $\begin{array}{l}\text { several times } \\
\text { a day }\end{array}$ & 99 & 17.28 & 100 & 17.70 \\
\hline & once-a-day & 108 & 18.85 & 72 & 12.74 \\
\hline & $\begin{array}{l}\text { several times } \\
\text { a week }\end{array}$ & 124 & 21.64 & 127 & 22.48 \\
\hline & $\begin{array}{l}\text { several times } \\
\text { a month }\end{array}$ & 72 & 12.57 & 85 & 15.04 \\
\hline & occasionally & 79 & 13.79 & 75 & 13.27 \\
\hline & never & 91 & 15.88 & 106 & 18.76 \\
\hline \multirow[t]{6}{*}{ Fruits } & $\begin{array}{l}\text { several times } \\
\text { a day }\end{array}$ & 346 & 60.38 & 285 & 50.44 \\
\hline & once-a-day & 138 & 24.08 & 143 & 25.31 \\
\hline & $\begin{array}{l}\text { several times } \\
\text { a week }\end{array}$ & 70 & 12.22 & 100 & 17.70 \\
\hline & $\begin{array}{l}\text { several times } \\
\text { a month }\end{array}$ & 11 & 1.92 & 20 & 3.54 \\
\hline & occasionally & 5 & 0.87 & 7 & 1.24 \\
\hline & never & 3 & 0.52 & 10 & 1.77 \\
\hline \multirow[t]{5}{*}{ Vegetables } & $\begin{array}{l}\text { several times } \\
\text { a day }\end{array}$ & 247 & 43.11 & 183 & 32.39 \\
\hline & once-a-day & 180 & 31.41 & 171 & 30.27 \\
\hline & $\begin{array}{l}\text { several times } \\
\text { a week }\end{array}$ & 104 & 18.15 & 136 & 24.07 \\
\hline & $\begin{array}{l}\text { several times } \\
\text { a month }\end{array}$ & 15 & 2.62 & 38 & 6.73 \\
\hline & occasionally & 16 & 2.79 & 19 & 3.36 \\
\hline
\end{tabular}

$(\mathrm{p}<0.01 ; \mathrm{V}=0.22)$. The obtained results indicate that the intake of these foods is lower among girls than boys (Tab. 5).

Analysis of the frequency of consumption of products not recommended for children's diet has shown that fast food and instant foods were eliminated from the diet of $7.16 \%$ and $45.03 \%$ of girls, respectively, v. $6.02 \%$ and $43.19 \%$ of boys, respectively.

A significant correlation between the respondents' sex and the frequency of fast food $(\mathrm{p}<0.01 ; \mathrm{V}=0.19)$ and instant food $(\mathrm{p}<0.01 ; \mathrm{V}=0.10)$ intake was identified, indicating the frequency of eating these products to be lower among girls than boys (Tab. 6).

Analysis of the sources of nutritional information has shown that children acquire knowledge from parents and teachers $61.08 \%$ of girls and $53.45 \%$ of boys, from the internet $-14.49 \%$ of girls and $14.34 \%$ of boys, from television programs $-11.52 \%$ of girls and $11.33 \%$ of boys. Among the respondents $1.22 \%$ of girls and $0.53 \%$ of boys don't acquire nutritional knowledge from any sources (Tab. 7).

\section{DISCUSSION}

Nutrition is one of the major environmental factors affecting human health and quality of life. Children's diets should be composed of good quality products, and be properly balanced, 
TABLE 4. Frequency of intake of animal-based foods, according to the respondents' sex

\begin{tabular}{|c|c|c|c|c|c|}
\hline \multirow{3}{*}{$\begin{array}{l}\text { Group } \\
\text { of food } \\
\text { products }\end{array}$} & \multirow{3}{*}{$\begin{array}{l}\text { Frequency } \\
\text { of intake of } \\
\text { selected foods }\end{array}$} & \multicolumn{4}{|c|}{ Sex } \\
\hline & & \multicolumn{2}{|c|}{ girls } & \multicolumn{2}{|c|}{ boys } \\
\hline & & $\mathrm{n}$ & $\%$ & $\mathrm{n}$ & $\%$ \\
\hline \multirow[t]{6}{*}{ Milk } & $\begin{array}{l}\text { several times } \\
\text { a day }\end{array}$ & 115 & 20.07 & 113 & 20.00 \\
\hline & once-a-day & 164 & 28.62 & 175 & 30.97 \\
\hline & $\begin{array}{l}\text { several times } \\
\text { a week }\end{array}$ & 163 & 28.45 & 144 & 25.49 \\
\hline & $\begin{array}{l}\text { several times } \\
\text { a month }\end{array}$ & 52 & 9.08 & 40 & 7.08 \\
\hline & occasionally & 37 & 6.46 & 30 & 5.31 \\
\hline & never & 42 & 7.33 & 63 & 11.15 \\
\hline \multirow[t]{6}{*}{$\begin{array}{l}\text { Natural } \\
\text { yoghurt }\end{array}$} & $\begin{array}{l}\text { several times } \\
\text { a day }\end{array}$ & 58 & 10.12 & 65 & 11.50 \\
\hline & once-a-day & 87 & 15.18 & 99 & 17.52 \\
\hline & $\begin{array}{l}\text { several times } \\
\text { a week }\end{array}$ & 174 & 30.37 & 140 & 24.78 \\
\hline & $\begin{array}{l}\text { several times } \\
\text { a month }\end{array}$ & 125 & 21.82 & 91 & 16.11 \\
\hline & occasionally & 64 & 11.17 & 77 & 13.63 \\
\hline & never & 65 & 11.34 & 93 & 16.46 \\
\hline \multirow[t]{6}{*}{$\begin{array}{l}\text { Cottage } \\
\text { cheese }\end{array}$} & $\begin{array}{l}\text { several times } \\
\text { a day }\end{array}$ & 38 & 6.63 & 38 & 6.73 \\
\hline & once-a-day & 76 & 13.26 & 98 & 17.35 \\
\hline & $\begin{array}{l}\text { several times } \\
\text { a week }\end{array}$ & 155 & 27.05 & 130 & 23.01 \\
\hline & $\begin{array}{l}\text { several times } \\
\text { a month }\end{array}$ & 132 & 23.04 & 96 & 16.99 \\
\hline & occasionally & 72 & 12.57 & 82 & 14.51 \\
\hline & never & 100 & 17.45 & 121 & 21.42 \\
\hline \multirow{6}{*}{$\begin{array}{l}\text { Cheese (hard } \\
\text { or processed } \\
\text { cheese) }\end{array}$} & $\begin{array}{l}\text { several times } \\
\text { a day }\end{array}$ & 74 & 12.91 & 111 & 19.65 \\
\hline & once-a-day & 157 & 27.40 & 143 & 25.31 \\
\hline & $\begin{array}{l}\text { several times } \\
\text { a week }\end{array}$ & 215 & 37.52 & 179 & 31.68 \\
\hline & $\begin{array}{l}\text { several times } \\
\text { a month }\end{array}$ & 56 & 9.77 & 50 & 8.85 \\
\hline & occasionally & 28 & 4.89 & 30 & 5.31 \\
\hline & never & 43 & 7.50 & 52 & 9.20 \\
\hline \multirow[t]{6}{*}{ Fish } & $\begin{array}{l}\text { several times } \\
\text { a day }\end{array}$ & 15 & 2.62 & 25 & 4.42 \\
\hline & once-a-day & 33 & 5.76 & 42 & 7.43 \\
\hline & $\begin{array}{l}\text { several times } \\
\text { a week }\end{array}$ & 171 & 29.84 & 166 & 29.38 \\
\hline & $\begin{array}{l}\text { several times } \\
\text { a month }\end{array}$ & 196 & 34.21 & 188 & 33.27 \\
\hline & occasionally & 96 & 16.75 & 92 & 16.28 \\
\hline & never & 62 & 5.45 & 52 & 9.20 \\
\hline \multirow[t]{6}{*}{ Meat } & $\begin{array}{l}\text { several times } \\
\text { a day }\end{array}$ & 98 & 17.10 & 154 & 27.26 \\
\hline & once-a-day & 218 & 38.05 & 212 & 37.52 \\
\hline & $\begin{array}{l}\text { several times } \\
\text { a week }\end{array}$ & 203 & 35.43 & 159 & 28.14 \\
\hline & $\begin{array}{l}\text { several times } \\
\text { a month }\end{array}$ & 27 & 4.71 & 23 & 4.07 \\
\hline & occasionally & 15 & 2.62 & 12 & 2.12 \\
\hline & never & 12 & 2.09 & 5 & 0.88 \\
\hline
\end{tabular}

TABLE 5. Frequency of intake of snacks and sweetened carbonated drink, according to the respondents' sex

\begin{tabular}{|c|c|c|c|c|c|}
\hline \multirow{3}{*}{$\begin{array}{l}\text { Group } \\
\text { of food } \\
\text { products }\end{array}$} & \multirow{3}{*}{$\begin{array}{c}\text { Frequency } \\
\text { of intake of } \\
\text { selected foods }\end{array}$} & \multicolumn{4}{|c|}{ Sex } \\
\hline & & \multicolumn{2}{|c|}{ girls } & \multicolumn{2}{|c|}{ boys } \\
\hline & & $\mathrm{n}$ & $\%$ & $\mathrm{n}$ & $\%$ \\
\hline \multirow[t]{6}{*}{ Salty snacks } & $\begin{array}{l}\text { several times } \\
\text { a day }\end{array}$ & 30 & 5.24 & 56 & 9.91 \\
\hline & once-a-day & 62 & 10.82 & 87 & 15.40 \\
\hline & $\begin{array}{l}\text { several times } \\
\text { a week }\end{array}$ & 169 & 29.49 & 164 & 29.03 \\
\hline & $\begin{array}{l}\text { several times } \\
\text { a month }\end{array}$ & 176 & 30.72 & 144 & 25.49 \\
\hline & occasionally & 119 & 20.77 & 96 & 16.99 \\
\hline & never & 17 & 2.97 & 18 & 3.19 \\
\hline \multirow[t]{6}{*}{ Sweets } & $\begin{array}{l}\text { several times } \\
\text { a day }\end{array}$ & 76 & 13.26 & 90 & 15.83 \\
\hline & once-a-day & 127 & 22.16 & 129 & 22.83 \\
\hline & $\begin{array}{l}\text { several times } \\
\text { a week }\end{array}$ & 187 & 32.64 & 173 & 30.62 \\
\hline & $\begin{array}{l}\text { several times } \\
\text { a month }\end{array}$ & 96 & 16.75 & 94 & 16.64 \\
\hline & occasionally & 74 & 12.91 & 67 & 11.86 \\
\hline & never & 13 & 2.27 & 12 & 2.12 \\
\hline \multirow{6}{*}{$\begin{array}{l}\text { Sweetened } \\
\text { carbonated } \\
\text { drinks }\end{array}$} & $\begin{array}{l}\text { several times } \\
\text { a day }\end{array}$ & 30 & 5.24 & 64 & 11.33 \\
\hline & once-a-day & 32 & 5.58 & 61 & 10.80 \\
\hline & $\begin{array}{l}\text { several times } \\
\text { a week }\end{array}$ & 113 & 19.72 & 135 & 23.89 \\
\hline & $\begin{array}{l}\text { several times } \\
\text { a month }\end{array}$ & 149 & 26.00 & 169 & 29.91 \\
\hline & occasionally & 185 & 32.29 & 99 & 17.52 \\
\hline & never & 64 & 11.17 & 37 & 6.55 \\
\hline
\end{tabular}

TABLE 6. Frequency of fast food and instant food intake

\begin{tabular}{|c|c|c|c|c|c|}
\hline \multirow{3}{*}{$\begin{array}{l}\text { Group } \\
\text { of food } \\
\text { products }\end{array}$} & \multirow{3}{*}{$\begin{array}{c}\text { Frequency } \\
\text { of intake of } \\
\text { selected foods }\end{array}$} & \multicolumn{4}{|c|}{ Sex } \\
\hline & & \multicolumn{2}{|c|}{ girls } & \multicolumn{2}{|c|}{ boys } \\
\hline & & $\mathrm{n}$ & $\%$ & $\mathrm{n}$ & $\%$ \\
\hline \multirow{5}{*}{$\begin{array}{l}\text { Fast food } \\
\text { products }\end{array}$} & once-a-day & 15 & 2.62 & 38 & 6.73 \\
\hline & $\begin{array}{l}\text { several times } \\
\text { a week }\end{array}$ & 52 & 9.08 & 95 & 16.81 \\
\hline & $\begin{array}{l}\text { several times } \\
\text { a month }\end{array}$ & 187 & 32.64 & 210 & 37.17 \\
\hline & occasionally & 278 & 48.52 & 188 & 33.27 \\
\hline & never & 41 & 7.16 & 34 & 6.02 \\
\hline \multirow{6}{*}{$\begin{array}{l}\text { "Instant" } \\
\text { food } \\
\text { products }\end{array}$} & $\begin{array}{l}\text { several times } \\
\text { a day }\end{array}$ & 12 & 2.09 & 13 & 2.30 \\
\hline & once-a-day & 13 & 2.27 & 28 & 4.96 \\
\hline & $\begin{array}{l}\text { several times } \\
\text { a week }\end{array}$ & 46 & 8.03 & 63 & 11.15 \\
\hline & $\begin{array}{l}\text { several times } \\
\text { a month }\end{array}$ & 85 & 14.85 & 100 & 17.70 \\
\hline & occasionally & 159 & 27.75 & 117 & 20.71 \\
\hline & never & 258 & 45.03 & 244 & 43.19 \\
\hline
\end{tabular}

i.e. include all nutrients to fulfil bodily needs [10]. With age, children become increasingly independent in their dietary choices, especially when eating outside the home. Hence the importance of establishing correct dietary patterns from a very young age 
TABLE 7. Sources of nutritional knowledge

\begin{tabular}{lcccc}
\multirow{2}{*}{\multicolumn{1}{c}{ Source of knowledge }} & \multicolumn{2}{c}{ girls } & \multicolumn{2}{c}{ boys } \\
\cline { 2 - 5 } & $\mathbf{n}$ & $\%$ & $\mathbf{n}$ & $\%$ \\
\hline From parents/teachers & 350 & 61.08 & 302 & 53.45 \\
\hline From the internet & 83 & 14.49 & 81 & 14.34 \\
\hline From newspaper/magazine & 21 & 3.66 & 11 & 1.95 \\
\hline From television programmes & 66 & 11.52 & 64 & 11.33 \\
\hline Other & 7 & 1.22 & 3 & 0.53 \\
\hline From age-mates & 15 & 2.62 & 18 & 3.19 \\
\hline I don't' deepen my knowledge & 31 & 5.41 & 86 & 15.22 \\
\hline
\end{tabular}

and continuous surveillance of children's diet to monitor and eliminate any dietary mistakes $[11,12]$.

According to the principles of proper nutrition, 4-5 daily meals are recommended for school-aged children, spaced out at appropriate time intervals. This ensures proper distribution of energy supply, thus reducing the risk of obesity, hypertension, atherosclerosis and diabetes [10]. In our study, more girls were found to eat the recommended number of daily meals than boys. The results of the study by Jonczyk et al., which covered pupils of primary schools in Piekary Śląskie, Poland, differed from ours. According to the authors, who evaluated e.g. the dietary patterns and physical activity levels of the pupils, a comparable proportion of boys and girls ate the recommended number of meals per day [13].

Breakfast is known to be the most important meal of the day, as it guarantees proper energy supply, and neglecting it may cause fatigue and concentration problems $[14,15]$. In our study, $72.2 \%$ of girls v. $73.27 \%$ of boys reported eating breakfast daily. Similar results were obtained by Jonczyk et al. in their study [13]. Wawrzyniak et al., on the other hand, reported less favourable results in their study evaluating breakfast consumption in a population of students in the Mazowieckie Voivodeship. According to that study, as little as $59 \%$ of students ate breakfast at home daily [2].

Water is crucial for proper functioning of the human body. It also provides necessary mineral elements. Among the students participating in our study, the amount of water drunk daily was insufficient, as confirmed by studies performed in other Polish voivodeships. In a study by Wojtyła-Bucior et al., conducted in 2015 , only $48 \%$ of pupils reported drinking water daily [4]. This may be due to the fact that children prefer sweetened carbonated drinks to water. It may also be associated with parents' inadequate knowledge about the importance of drinking water and the actual needs of children regarding daily water intake, as demonstrated by Wyka et al., who evaluated the dietary knowledge of parents of school-aged children. They found that as few as 10 out of 195 parents participating in their study were able to select the correct answer regarding the amount of water that children should drink daily [16].

Fruits and vegetables are rich sources of vitamins and other nutrients. They also contain considerable amounts of fibre and natural anti-oxidants $[8,17]$. According to the principles of a healthy diet, fruits and vegetables should be eaten as often as possible, in the largest possible quantities [3]. The results of our study suggest a greater intake of fruits and vegetables among girls than boys. Different results, however, were obtained in a survey carried out in 38 randomly selected primary schools from 4 voivodeships as a part of the "Fruit in school" programme. The voivodeships included were Mazowieckie, Podkarpackie, Pomorskie and Wielkopolskie. According to the findings of that survey, fruit and vegetable intake was significantly higher among boys than girls [8].

Milk and dairy products, in turn, are abundant sources of protein and calcium. Throughout childhood, optimal bone mass and mineral density are developed. Calcium, most readily available in milk and dairy products, is essential for the prevention of osteoporosis $[6,18]$. Children are recommended to drink 3-4 glasses of milk daily, or replace milk with adequate amounts of other dairy products, e.g. yoghurt, kefir, or cottage cheese $[6,9,16]$. In our study, milk and dairy intake was found to be inadequate, with boys found to consume natural yoghurt and cottage cheese more frequently than girls. The results are similar to those obtained by Jonczyk et al., who found that $49.61 \%$ of girls v. $56.7 \%$ of boys in their study drank milk or ate dairy daily [13]. In recent years, the prevalence of overweightness and obesity in children has soared, a fact associated with high-calorie diets and insufficient levels of physical activity in children, resulting in food intake disproportionate to actual energy expenditure, thus leading to an increase in body weight $[19,20]$. High-calorie products, such as sweets, sweetened carbonated drinks and salty snacks have in many cases replaced milk, dairy products, fruits and vegetables in children's daily diet [21]. This dietary trend is also known to contribute to the development of caries [8, 22]. The findings of many studies confirm that the frequent consumption of these products by children is a common problem $[1,4$, $13,23,24]$. In our study, no correlation was identified between the respondents' sex and their intake of sweets. Szeja et al., on the other hand, assessing dietary patterns of girls and boys in sports-profiled schools or classes, found girls to eat sweets more frequently than boys [25]. In our study, salty snacks and sweetened carbonated drinks were consumed more frequently by boys. Similar results, indicating higher intake of these products among boys, were also demonstrated by Vanderlee et al. and Wuenstel et al. [26, 27].

Our study has also shown that boys ate fast food and instant foods more frequently than girls. Similar results were obtained in a study conducted by Jonczyk et al. in Piekary Śląskie. According to their findings, $59 \%$ of boys v. $5.08 \%$ of girls ate fast food meals at least on a weekly basis, and $27.78 \%$ of boys v. $23.44 \%$ of girls - less than once a week [13]. A study conducted among parents of pupils from the Śląskie and Opolskie Voivodeships yielded different results, with the parents' answers indicating that $83 \%$ of children ate out at fast food restaurants less frequently than once a month, $11.98 \%$ of boys and $11.40 \%$ of girls less than once a week, and only $3.23 \%$ of boys and $4.66 \%$ of girls - at least once a week [1].

The growing prevalence of overweightness and obesity in children as a result of unhealthy dietary patterns warrants 
continuous surveillance of children's diets. Despite increasing nutritional awareness and knowledge of the possible consequences of inadequate nutrition, more comprehensive nutritional education is necessary, adjusted to the needs of young consumers and their caregivers, as indicated by numerous researchers in the field $[5,7,9,28,29]$.

\section{CONCLUSIONS}

1. Some unhealthy dietary patterns have been identified among both school-aged girls and boys, with girls found to have more favourable dietary patterns.

2. Statistically significant correlations have been identified between the majority of dietary behaviours and the respondents' sex.

3. The results of the study indicate a need for more intense nutritional education among primary school pupils, diversified for boys and girls.

\section{REFERENCES}

1. Jonczyk P, Potempa M, Kajdaniuk D. Analiza stopnia odżywienia i zaburzeń odżywiania oraz charakterystyka przyzwyczajeń żywieniowych i aktywności fizycznej wśród dzieci w wieku 6-13 lat uczęszczających do wybranych szkół podstawowych na terenach wiejskich województw śląskiego i opolskiego. Pediatr Med Rodz 2016;12(2):177-93.

2. Wawrzyniak A, Sadurska J, Hamułka J. Ocena spożycia śniadań oraz spożycia energii z produktami kupowanymi w sklepikach szkolnych przez uczniów. Probl Hig Epidemiol 2015;96(1):254-8.

3. Jarosz M, editor. Normy żywienia dla populacji polskiej - nowelizacja. Warszawa: Instytut Żywności i Żywienia; 2017. https://ncez.pl/abc-zywienia/zasady-zdrowego-zywienia/normy-zywienia-2017 (12.04.2018).

4. Wojtyła-Buciora P, Żukiewicz-Sobczak W, Wojtyła K, Marcinkowski JT. Sposób żywienia uczniów szkół podstawowych w powiecie kaliskim w opinii dzieci i ich rodziców. Probl Hig Epidemiol 2015;96(1):245-53.

5. Storcksdieck genannt Bonsmann S. Comprehensive mapping of national school food policies across the European Union plus Norway and Switzerland. Nutr Bull 2014;39(4):369-73.

6. Kotyrba J, Wróblewska I. Analiza zachowań żywieniowych dzieci klas III-V szkoły podstawowej. Puls Uczelni 2014;8(3):11-5.

7. Walosik A, Jancarz-Łanczkowska B. Edukacja szkolna w zakresie odży wiania się jako warunek zachowania zdrowia człowieka. Eduk Biol Środ 2016;3(60):100-8.

8. Wolnicka K, Jaczewska-Schuetz J, Taraszewska A. Analiza czynników wpływających na spożycie warzyw i owoców przez dzieci w wieku szkolnym. Probl Hig Epidemiol 2014;95(2):389-93.

9. Krajewska M, Balcerska A, Kołodziejska A, Stefanowicz A. Analiza stylu odżywiania i aktywności fizycznej u dzieci i młodzieży z nadmierną masą ciała - zalecenia dla pacjentów i opiekunów. Forum Med Rodz 2014;8(2):98-104.

10. Sosnowska-Bielicz E, Wrótniak J. Nawyki żywieniowe a otyłość dzieci w wieku przedszkolnym i szkolnym. Lubelski Rocznik Pedagogiczny 2013;32:147-65.
11. Zalewska M, Maciorkowska E. Rola edukacji żywieniowej w populacji dzieci i młodzieży. Med Og Nauk Zdr 2013;19(3):375-8.

12. Daniels SR, Hassink SG, COMMITTEE ON NUTRITION. The Role of the Pediatrician in Primary Prevention of Obesity. Pediatrics 2015;136(1):e275-92.

13. Jonczyk P, Potempa M, Kajdaniuk D. Analiza stopnia odżywienia i zaburzeń odżywiania oraz charakterystyka przyzwyczajeń żywieniowych i aktywności fizycznej wśród dzieci szkolnych w wieku 6-13 lat w mieście Piekary Śląskie. Pediatr Med Rodz 2015;11(3):302-14.

14. Hałacz J, Warechowska M. Ocena sposobu żywienia dzieci w wieku 10-12 lat mieszkających w Olsztynie. Pediatr Endocrinol Diabetes Metab 2015;21(1):23-31.

15. Boyland EJ, Jason Halford JCG. Television advertising and branding. Effects on eating behaviour and food preferences in children. Appetite 2013;62:236-41.

16. Wyka J, Grochowska-Niedworok E, Malczyk E, Misiarz M, Hołyńska K. Wiedza żywieniowa rodziców oraz występowanie nadwagi i otyłości wśród dzieci w wieku szkolnym. Bromat Chem Toksykol 2012;45(3):680-4.

17. Kłosiewicz-Latoszek L. Zalecenia żywieniowe w prewencji chorób przewlekłych. Probl Hig Epidemiol 2009;90(4):447-50.

18. Ambroży J, Bester J, Czuchraj W, Dostał K, Dubiel M. Nawyki żywieniowe oraz częstość spożycia wybranych produktów przez dzieci w wieku 10-13 lat zamieszkałe na terenach miejskich i wiejskich. Ann Acad Med Siles 2013;67(4):231-7.

19. Stankiewicz M, Pieszko M, Śliwińska A, Małgorzewicz S, Wierucki $Ł, Z d r o j e w s k i ~ T$, et al. Występowanie nadwagi i otyłości oraz wiedza i zachowania zdrowotne dzieci i młodzieży małych miast i wsi - wyniki badania Polskiego Projektu 400 Miast. Endokrynol Otył Zab Przem Mat 2010;6(2):59-66.

20. Papandreou D, Andreou E, Heraclides A, Rousso I. Is beverage intake related to overweight and obesity in school children? Hippokratia 2013;17(1):42-6.

21. Szczepańska E, Piórkowska K, Niedworok E, Muc-Wierzgoń M. Konsumpcja słodyczy i napojów wysokosłodzonych w aspekcie występowania otyłości na przykładzie dzieci zamieszkujących obszary miejskie i wiejskie. Endokrynol Otył Zab Przem Mat 2010;6(2):78-84.

22. Wójcicka A, Zalewska M, Czerech E, Jabłoński R, Grabowska SZ, Maciorkowska E. Próchnica wieku rozwojowego chorobą cywilizacyjną. Prz Epidemiol 2012;66(4):705-11.

23. Wojtyła-Buciora P, Stawińska-Witoszyńska B, Klimberg A, Wojtyła A, Goździewska M, Wojtyła K, et al. Nutrition-related health behaviours and prevalence of overweight and obesity among Polish children and adolescents. Ann Agric Environ Med 2013;20(2):332-40.

24. Stefańska E, Falkowska A, Ostrowska L. Wybrane zwyczaje żywieniowe dzieci i młodzieży w wieku 10-15 lat. Rocz Panstw Zakl Hig 2012;63(1): 91-8.

25. Szeja N, Szczepańska E, Janion K, Szymkiewicz A, Lenard B, Dudzik I, et al. Selected eating behaviours of girls and boys attending sport-oriented classes. Rocz Panstw Zakl Hig 2017;68(1):83-90.

26. Vanderlee L, Manske S, Murnaghan D, Hanning R, Hammond D. Sugarsweetened beverage consumption among a subset of Canadian youth. J Sch Health 2014;84(3):168-76.

27. Wuenstel JW, Wądołowska L, Słowińska MA, Niedźwiedzka E, Kowalkowska J, Antoniak L. Consumption frequency of fruit juices and sweetened beverages: differences related to age, gender and the prevalence of overweight among polish adolescents. Pol J Food Nutr Sci 2015;65(3): 211-21.

28. Sielicka M, Pachołek B, Matuszak L, Gabryelczyk M, Majos A. Ocena świadomości zdrowotnej i pożądalności produktów przekąskowych przez dzieci. Probl Hig Epidemiol 2015;96(3):607-12.

29. Decyk-Chęcel A. Zwyczaje żywieniowe dzieci i młodzieży. Probl Hig Epidemiol 2017;98(2):103-9. 